\title{
ERRATUM
}

The Journal of Microbiology (2012) Vol. 50, No. 2, pp. 226-234

Copyright (C) 2012, The Microbiological Society of Korea

\section{Effect of Natural Mediators on the Stability of Trametes trogii Laccase during the Decolourization of Textile Wastewaters}

\author{
Rim Khlifi-Slama ${ }^{1 \# \star}$, Tahar Mechichi ${ }^{2}$, Sami Sayadi ${ }^{1}$, and Abdelhafidh Dhouib ${ }^{1}$ \\ ${ }^{1}$ Laboratory of Environmental Bioprocesses, Centre of Biotechnology of Sfax, University of Sfax, \\ Sidi Mansour Road Km 6, PB 1177, 3018 Sfax, Tunisia \\ ${ }^{2}$ Ecole Nationale d'Ingenieurs de Sfax, Laboratory of Enzyme Engineering and Microbiology, University of Sfax, \\ Soukra Road Km 4, BP 1173, 3038 Sfax, Tunisia \\ ${ }^{\#}$ Present address: Marine Ecotoxicology, UR 09-03, Sfax University, IPEIS, BP 805-3018, Sfax, Tunisia
}

In the article by Khlifi-Slama et al. that appears in the Journal of Microbiology 2012; 50, 226-234. Page 226, first author name should read as Rim Khlifi. 